\title{
Language and translation practices of Spanish-language newspapers published in the U.S. borderlands between 1808 and 1930
}

\author{
Laura Gasca Jiménez \\ Fairfield University, Igascajimenez1@fairfield.edu
}

Maira E. Álvarez

Sylvia Fernández

Follow this and additional works at: https://digitalcommons.fairfield.edu/modernlanguagesandliteraturefacultypubs

(c) 2019 John Benjamins Publishing Company. All rights reserved. The post-print version has been archived here with permission from the copyright holder.

\section{Peer Reviewed}

\section{Repository Citation}

Jiménez, Laura Gasca; Álvarez, Maira E.; and Fernández, Sylvia, "Language and translation practices of Spanish-language newspapers published in the U.S. borderlands between 1808 and 1930" (2019). Modern Languages \& Literature Faculty Publications. 52.

https://digitalcommons.fairfield.edu/modernlanguagesandliterature-facultypubs/52

\section{Published Citation}

Gasca Jiménez, Laura, Maira E. Álvarez, and Sylvia Fernández. "Language and translation practices of Spanishlanguage newspapers published in the US borderlands between 1808 and 1930." Translation and Interpreting Studies: The Journal of the American Translation and Interpreting Studies Association 14, no. 2 (2019): $218-242$. https://doi.org/10.1075/tis.00039.gas.

This item has been accepted for inclusion in DigitalCommons@Fairfield by an authorized administrator of DigitalCommons@Fairfield. It is brought to you by DigitalCommons@Fairfield with permission from the rightsholder(s) and is protected by copyright and/or related rights. You are free to use this item in any way that is permitted by the copyright and related rights legislation that applies to your use. For other uses, you need to obtain permission from the rights-holder(s) directly, unless additional rights are indicated by a Creative Commons license in the record and/or on the work itself. For more information, please contact digitalcommons@fairfield.edu. 


\title{
The Language and Translation Practices of Spanish-language Newspapers Published in the U.S. Borderlands between 1808 and 1930
}

\author{
Laura Gasca Jiménez (Fairfield University) \\ Maira E. Álvarez (University of Houston) \\ Sylvia Fernández (University of Houston)
}

\begin{abstract}
This article examines the impact of the anglicizing language policies implemented after the annexation of the U.S. borderlands to the United States on language use by describing the language and translation practices of Spanish-language newspapers published in the U.S. borderlands across different sociohistorical periods from 1808 to 1930. Sixty Hispanic-American newspapers (374 issues) from 1808 to 1980 were selected for analysis. Despite aggressive anglicizing legislation that caused a societal shift of language use from Spanish into English in most borderland states after the annexation, the current study suggests that the newspapers resisted assimilation by adhering to the Spanish language in the creation of original content and in translation.
\end{abstract}

Keywords: translation practices, language practices, Spanish-language newspapers, borderlands, language use, language maintenance 


\section{Introduction}

According to the latest demographic figures of Hispanics or Latinos in the United States, the Hispanic population has grown from 14.8 million in 1980 (6.5\% of the total population) to 55.3 million in 2014 (17.3\% of the total population), making it the country's largest minority (Pew Research Center 2016a). ${ }^{1}$ By 2060, the U.S. Census Bureau projects that these figures will increase to 119 million ( $29 \%$ of the total population). Historically the southwest states have registered the largest number of Hispanics, with almost half of the total Hispanic population in 2010 living in California and Texas. Today California (15 million) and Texas (10.4 million) are home to two of the largest Hispanic populations (Pew Research Center 2016a).

This constant flux of demographic figures is mirrored in the figures surrounding language use in the United States. According to an article titled The Nation's Latino Population Is Defined by Its Youth by the Pew Research Center (2016b), English use among Hispanic adults is on the rise, with approximately $62 \%$ of adult Hispanics in the U.S. reporting to speak English or being bilingual. Among younger Hispanics (ages 5-17), English language proficiency is very common $(88 \%)$, while proficiency in Spanish is less so $(62 \%)$. The number of Hispanics who speak Spanish at home seems to be declining, while the number of those who speak English only in the home appears to be increasing.

Historically, language policies in the United States have been characterized by the imposition of English across social domains and the devaluation of minoritized languages. However, in comparison with other minoritized languages in the U.S. such as German, Spanish has shown a stronger resistance to this linguistic imposition (Balestra, Martínez, and Moyna 2008: 35). In large part, Hispanic communities have retained the use of Spanish due to the geographic concentration of Latinos in certain areas and the regular arrival of new immigrants (Bills, Hernández-Chávez, and Hudson 1995). Other variables, such as the widespread use of the language and a thriving Spanish-language media sector appear to stem assimilation of Spanishlanguage speakers into English and the loss of community languages (Carreira 2013). Nevertheless, despite the regular use of Spanish in these communities, Spanish language proficiency of community members continues to decrease as the result of the dominance and marked prevalence of English in public settings (Potowski 2010).

Notwithstanding language proficiency, the use of Spanish in Hispanic communities remains a key component to maintaining cultural identity. According to the Center for Spanish Language Media (2011), there were over 800 Spanish-language newspapers and 500 magazines circulating throughout the United States in 2011. As Carreira (2013) asserts, the media plays a significant role in advocating for local Hispanic communities and maintaining the language and the culture. She contends that, in addition to instilling a sense of community, Spanish-language media raises the visibility of Spanish and provides valuable linguistic input.

Since the publication of the first Spanish-language newspapers in the southwest of the

\footnotetext{
${ }^{1}$ The terms Hispanic and Latino are used interchangeably throughout this article. All back translations are our own unless otherwise indicated.
} 
present United States in 1808 (El Misisipí) and 1809 (El Mensagero Luisanés), Hispanic communities across the country have supported newspapers edited by and for Latinos. These publications have served, and continue to serve, multiple functions, from informing the community about current affairs to resisting acculturation and assimilation to the Anglo-Saxon culture and the English language (Kanellos 1993: 107-108).

Throughout the second half of the nineteenth century, Spanish-language newspapers, published primarily by interest groups, writers' associations, labor unions, political organizations, and individuals, sustained the Hispanic immigrant print culture in the southwest (Kanellos 2011: 38). While some newspapers were geared toward specialized audiences, many were directed to the entire Hispanic community, "with articles that appealed to workers as well as to middle- and upper-class readers and, through the fashion and food pages, even to middle-class women" (Kanellos 2011: 39). The topics covered in these newspapers are still relevant today since they address contemporary concerns of the Hispanic community such as bilingualism and language maintenance (Lazo and Aleman 2016).

This article examines the impact of the anglicizing language policies implemented after the annexation of the U.S. borderlands to the United States on language use by describing the language and translation practices of Spanish-language newspapers published in the U.S. borderlands across different sociohistorical periods from 1808 to 1930 . The present study aligns with Garner's (1987: 5) assertion that newspapers are invaluable sources to the study of language attitudes across time. More specifically, we examine three questions related to language and translation practices using a linguistically-oriented approach that have not yet been explored within the context of Hispanic-American periodicals research:

1. When and where did translations begin in Spanish-language newspapers?

2. What sections were translated and what translation strategies were followed?

3. Did Spanish-language newspapers follow an anglicizing pattern? ${ }^{2}$

First, we outline the complex and extensive sociohistorical context covered by this study followed by the methodology adopted to address these questions. Then, we present the main differences found in terms of translation practice and explore the specific translation strategies adopted by the Spanish-language newspapers. These findings are contextualized in relation to potential anglicizing patterns across the four historical periods. We conclude by reflecting on general trends in the use of the Spanish language in content creation and translation.

\section{Sociohistorical context}

To offer an overview of the sociohistorical context covered in this article, we adopt Leal's (1973) periodization - originally developed to describe the origins of Mexican-American literature - as a point of departure. The names of each period have been maintained; however, the dates have

\footnotetext{
${ }^{2}$ The term "anglicizing" refers here to a shift from Spanish to English in language use.
} 
been adjusted slightly to account for historical events that had an impact on language use. For each period, such historical events will be briefly described as well as the newspaper production.

\section{The Hispanic Period (1513-1820)}

The first period is characterized by several important events that had a significant impact on Spanish language use in the Americas. First, and perhaps most notably, is the introduction of the Spanish language itself. Written Spanish was introduced for the first time in America in 1513 with the diaries of Juan Ponce de León, Spanish explorer and conquistador. Following Juan Ponce de León's expedition, the Spanish language quickly spread to the north of New Spain and to the lands that would become part of the United States by the middle of the nineteenth century as a result of the conquest, annexation, and purchase of territories (Kanellos and Balestra 2002: xii).

Subsequently, the introduction and importation of books and the printing press, as well as the publication of the first Spanish-language newspapers in the borderland states of Louisiana and Texas, all had an important impact during this time period. In Mexico, licenses to import books began to be granted in 1525, with the first printing press introduced in 1534 by Esteban Martín. The first commercial Mexican printing press was established a few years later, in 1539, by Juan Cromberger, printer and owner of a well-known printing house in Seville (Castañeda 1940). By the mid-sixteenth century, seven printers were operating in Mexico City. In addition to books, the first Mexican press published occasionally newssheets called hojas volantes (flying sheets) - often considered the precursor to newspapers - and typically described a single event of public interest and did not appear at regular intervals ${ }^{3}$. The first hoja volante was published in 1541 in Juan Cromberger's press. Their publication continued throughout the seventeenth and into the early eighteenth century (Garner 1987), and starting in eighteenth century, these serial publications started to appear at regular intervals. The first periodical, Mercurio Volante, appeared in 1693 and the first true newspaper, La Gazeta de México y noticias de Nueva España, in 1722 (Kanellos and Martell 2000). Printed monthly, it consisted of two pages, one editorial and another dedicated to news from European sources, which also included a small section about recently published books (Argudín 1987: 18-19). Six years later, it was followed by Gaceta de México. According to Argudín (1987: 20), gacetas, or circulars, were considered indicators of the illustration level reached by a city and contributed to showcase the artistic activities that were taking place in the New World.

The first Spanish press was introduced in Louisiana at the end of the eighteenth century. After the Louisiana Purchase (1803), a significant influx of Anglo-Americans into the region resulted in Hispanic community becoming a minority in the region. The first Spanish-language newspapers, El Misisipí and El Mensagero Luisanés, appeared a few years after the Louisiana Purchase, in 1808 and 1809 respectively. These were followed by La Gaceta de Texas and El

\footnotetext{
${ }^{3}$ The introduction of books into the Americas has been viewed not only as a means of imposing the Spanish language on the local population, but also as a primary mechanism to evangelize the native populations (Castañeda 1940: 679, see also Valdeón 2014).
} 
Mexicano in Texas in $1813^{4}$, El Telégrafo de las Floridas in Florida in 1817, and others in Louisiana, Texas, and the northeast (Kanellos and Martell 2000: 4-5). ${ }^{5}$

\section{The Mexican Period (1821-1848)}

The Mexican Period is characterized by an increased use of English in the borderlands and the introduction of printing presses in California and New Mexico. The increased presence of English began shortly after Mexico gained independence from Spain in 1821 and the borderlands became part of the Republic of Mexico. The intervening years after independence were largely unstable and saw a rise of American settlers, traders, and trappers throughout the borderlands. With an increased number of Anglo-American newcomers who were unwilling to assimilate, the local Mexican population was quickly outnumbered in most states, with the lone exception being the state of New Mexico (Perrigo 1960).

The first presses in California and New Mexico were introduced in 1834. In New Mexico, the press entered service almost immediately. The first nuevomexicano newspaper, $E l$ Crepúsculo de la Libertad, is believed to have been published in 1834 in Santa Fe. The first Spanish-language newspaper would not appear in California until the 1850s.

The end of the Mexican period is marked by the declaration of independence of settlers in Texas from Mexico in 1836. This tumultuous time period ultimately led to the state of Texas being annexed by the United States in 1845; however, a significant diplomatic rupture between the U.S. and Mexico as a result of this decision resulted in the Mexican-American War (18461848). The conflict ended with the signing of the Treaty of Guadalupe Hidalgo in 1845, which compensated Mexico in the amount of $\$ 15$ million for the lands that are today New Mexico, Arizona, and California.

\section{The Transition Period (1849-1909)}

The Transition Period is defined by the dominance of English and the flourishing of Spanishlanguage newspapers. The shift from Spanish into English varied across states; however, by the end of this period, each region saw English as the dominant language of use in public settings.

Policies in these areas followed a pattern of anglicization with the express purpose of achieving cultural and linguistic assimilation of those who used languages other than English (Hernández-Chávez 1993: 145). For example, the California Constitution of 1849 allowed for the publication of laws in Spanish and English; however, legislation passed in 1862-63 restricted the laws that could be published in Spanish (Hernández-Chávez 1993: 46). Likewise, the education system in California shifted in favor of English dominance. During the Hispanic and Mexican periods in California, formal education was quite limited. After the annexation, AngloAmericans developed an educational system with English as the language of instruction as specified by the California Constitution of 1855 (Balestra, Martínez, and Moyna 2008: 39).

\footnotetext{
${ }^{4}$ These newspapers were printed in Natchitoches, Louisiana (Gutiérrez 1977: 37).

${ }^{5}$ For a chronological index, see Kanellos and Martell (2000).
} 
Finally, the California Constitution of 1879 eliminated all official use of Spanish.

Texas had similar experiences with language dominance after annexation. In 1856, the use of Spanish was allowed in counties with large Mexican populations. However, according to Hernández-Chávez (1993: 46), "laws concerning the use of Spanish were passed not in the interests of the people, but for the convenience of the State in administering the laws." Two years later, in 1858, English became the language of instruction in schools and in 1905 a new law was passed that specified that all instruction had to be in English with the sole exception being for foreign language coursework (Kloss 1977: 175).

New Mexico, however, differed from Texas and California in that the Hispanic population remained the largest demographic group after annexation. As a result, Spanish continued to be the dominant language in public settings as well as the language of instruction in public schools. Laws restricting the use of Spanish were not passed until New Mexico became a state in 1912. At that time, the English-speaking population began to increase in the area, which ultimately led to increased pressure to teach and use English (Hernández-Chávez 1993: 148).

However, despite the borderlands being a site of linguistic imposition, there was also resistance to English-only policies and a defense of the Spanish language. This resistance manifested, in part, by means of the publication of Spanish-language newspapers, which flourished after annexation. In Rosales' (2000: 26) words, Hispanics in the southwest "published hundreds of Spanish-language newspapers to cover not only news and advertising but also to support their own ideas, language and culture." The newspapers fulfilled different functions, which ranged from providing news and advertisements for local businesses to serving as forums for intellectuals, writers, and politicians (Kanellos and Martell 2000). Moreover, the newspapers sponsored cultural events and served as an organizational platform for community related to social and political action. They also were the main publishers of creative literature in Spanish, including poetry, prose, serialized novels, and plays (Kanellos and Martell 2000: 5-8). As Kanellos and Martell (2000: 7) emphasize, newspapers facilitated the preservation of culture and the education of the community as they "offered the best examples of writing in the vernacular."

By 1870 Spanish-language newspapers were widespread in the southwest and, by 1891 , Hispanic journalism had to the point that a newspaper association was founded, La Prensa Asociada Hispano-Americana (Kanellos and Martell 2000: 79). It is estimated that approximately 2,500 newspapers were published between 1808 and 1960 .

California's first Spanish-language newspaper appeared in San Francisco in 1854, La Crónica, followed in 1855 by El Clamor Público. Treviño (1989: 9) explains the rise of the Spanish-language press "as a conscious effort to preserve mexicano cultural integrity." California was one of the first states to reflect on the importance of preserving the Spanish language and to recognize the need to learn English (Kanellos and Martell 2002). Some editors promoted English-language learning in order to protect the rights of the Hispanic community, while others emphasized the preservation of Spanish. Francisco P. Ramírez, founder of El Clamor Público (1855: 59), is considered the first Mexican-American journalist of the southwest to use the press to demand rights for the Hispanic community. According to Kanellos and Martell 
(2000: 89), "he became a consistent and assiduous critic, attempting to inspire Hispanics to unite in their own defense and to spur the authorities to protect the Hispanic residents of California." By 1880, a new sense of biculturalism started to arise in California with the Spanish-language press advocating for the integration into the American political and educational system and supporting the learning of English (Treviño 1989).

In the 1850s, newspapers in Texas, like in California, fulfilled activist roles in favor of the Mexican and Mexican-American population. According to Kanellos and Martell (2000: 100), La Crónica (1909-19??) published by Nicasio Idar was one of the most influential newspapers in Texas. Through La Crónica and a magazine called La Revista de Laredo (191?19??), Idar and his family fought against racism and negative stereotypes, and plead for the rights of the native Mexican population. Other newspapers such as El Defensor del Pueblo (1906-19??) by Santiago G. Guzmán focused on the development and promotion of Mexican-American identity. Kanellos and Martell (2000: 103) indicate that Guzmán "envisioned his paper as a guardian of those rights and as a beacon for guiding Mexican Americans in combating racism and shucking off their sense of inferiority."

In New Mexico, many publishers saw newspapers as key to education and the protection of the rights of the Hispanic community (Meléndez 2005). After the arrival of the railroad, journalism increased dramatically in New Mexico. By 1890s, it is estimated that thirty-five Spanish-language newspapers were being published in this territory (1997: 26), leaving "the English-language and bilingual newspapers to serve a mostly English-speaking elite, while Spanish-language papers served the majority of inhabitants" (Kanellos and Martell 2000: 79). According to Meléndez (2005) and Kanellos and Martell (2000), the nuevomexicano journalists sought to build a national culture for themselves by celebrating and preserving the Spanish language and defending their history and literature.

\section{The Interaction Period (1910-1930)}

This last period is characterized by the arrival of new Spanish-speaker immigrants in the borderlands. In 1910, the results of the election in Mexico were nullified, which led to the start of the Mexican Revolution in 1911 "as a national socialist effort to overthrow Dictator Porfirio Diaz and institute social justice" (Kanellos 1995: 163). The revolution significantly impacted in the United States borderlands, as many Mexican immigrants crossed the border in search of security and work. Most of these immigrants never returned to Mexico and their children became American citizens by birth (Leal 1973: 39). According to Kanellos (1995), the influx of new immigrants reinforced and transformed Hispanic culture in the United States, as political refugees of the elite class assumed leadership roles in Hispanic communities.

\section{Methods}

The entire corpus comprises hundreds of newspapers published in English and Spanish between 1808 and 1960 in the United States, which can be accessed through the Hispanic-American 
Newspapers 1808-1980 collection in Readex, a division of Newsbank. ${ }^{6}$ For this study, 60 newspapers (374 issues) were selected for analysis (see the Appendix for a complete list). This material is identified as U.S. borderlands newspapers according to criteria established by Borderlands Archives Cartography, ${ }^{7}$ a transnational project that locates, maps, and facilitates access to nineteenth and mid-twentieth century newspapers from the U.S.-Mexico borderlands:

- Newspapers published in the borderlands (California, Arizona, New Mexico, Texas, Louisiana)

- Newspapers published in Spanish (newspapers published exclusively in English were excluded)

The 374 selected issues were individually analyzed and the following information was coded for each: newspaper title, historical period, date of publication, territory, and language. To periodize the data, the previously described historical periods were used. To code for language, each issue was classified as monolingual, bilingual, translated or bilingual, and translated. For the purposes of this study, these terms were defined as follows:

- Monolingual (M): newspaper issue that is written exclusively in Spanish.

- Bilingual (B): newspaper issue that uses English and Spanish across sections.

- Translated (T): newspaper issue that includes EN-ES translations of whole sections and/or section fragments.

- Bilingual and translated (BT): newspaper issue that uses English and Spanish across sections and includes EN-ES translations of whole sections and/or section fragments.

Translations of any type were considered for analysis. It should be noted that the number of issues included in the first two historical periods is very limited given the relatively few newspapers in circulation at the time and for reasons related to data access and availability. Each issue also varied in size and circulation.

\section{Results}

In response to the first research question as to the translation practices in Spanish-language newspapers, significant differences were found across the four historical periods (see Table 1). The first issues with translations appeared during the second period under discussion, namely the Mexican Period, with the translated texts largely being advertisements. During this period, English began to appear in some newspaper sections. Half of the issues studied within this historical period are classified as bilingual translations $(50 \%)$, one as a translation (10\%), three as bilingual (30\%), and one as monolingual (10\%). In contrast, all the issues published during the

\footnotetext{
${ }^{6}$ The newspapers analyzed were recovered by Recovering the U.S. Hispanic Literary Heritage Project, an international program founded and directed by Nicolás Kanellos that locates, preserves, and disseminates Hispanic culture of the United States in its written form since colonial times until 1960.

${ }^{7}$ https://www.bacartography.org
} 
previous historical period are monolingual (see Table 1 and Figure 1). The issues identified as being translations or bilingual translations during the Mexican Period belong to the same newspaper, L'Abeille.

During the Transition Period, the number of publications and the number of issues with translations increased. In many instances, English and Spanish were used in issues across different sections; issues also included translated sections and were, therefore, classified as both bilingual and translated. Some newspapers stated that they used both languages: "this paper publishes in English and Spanish" (La Flor del Valle, 3 February 1894), "este semanario se redactará en castellano y en inglés" [this weekly will be published in Spanish and English] ( $E l$ Defensor del Pueblo, 7 March 1891, our translation). During this period, it was also common to find advertisements of translators who offered their professional services:

Francisco P. Ramírez, Traductor del Francés, Inglés y Español. Traducciones del Inglés al Español y del Español al Francés, y viceversa, se hacen con mucho cuidado y fidelidad. Ocúrrase a esta Imprenta. [Francisco P. Ramírez, French, English and Spanish Translator. Translations from English to Spanish and Spanish to French, and vice versa, done with great care and fidelity. Contact this printing house.]

(Clamor Público, 28 June 1856, our translation)

Most of the issues analyzed within this period are classified as BT (64.5\%) and $\mathrm{T}(23.8 \%)$ with just a few classified as $\mathrm{M}(8.7 \%)$ and $\mathrm{B}(2.9 \%)$. The number of issues with translations continued to increase during the Interaction Period with nearly all the issues classified as BT (77.8\%) and T (15.3\%), in comparison to a few $\mathrm{M}(3.2 \%)$ and B (3.7\%).

[Table 1. Language practices in Hispanic newspapers across historical periods]

[Figure 1. Language practices in Hispanic newspapers across historical periods]

If the data are examined state-by-state, the first issues with translations appeared in newspapers published in Louisiana during the Mexican Period. All of the newspapers from the state of Louisiana were classified as B (33.3\%), T (11.1\%), and BT (55.6\%). However, given the limited number of existing and located newspapers, only issues from the states of Louisiana and New Mexico could be analyzed, and therefore this observation is made tentatively.

During the Transition Period, the language practices of newspapers in each state were very similar and no significant differences were found (see Table 2). The vast majority of issues analyzed for each state during this period were bilingual, translated, or both. In three states (California, Texas, and New Mexico), over $80 \%$ of newspapers could be classified in these categories, which is indicative of the significant presence of English and Spanish in print media. The same holds true in Arizona and Louisiana; however, the limited number of issues available makes generalizations impossible to make.

[Table 2. Language practices during the Transition Period] 
During the Interaction Period, however, language practices differed significantly between the states of California, New Mexico, and Texas (see Table 3). It should be noted that there were no issues available for Arizona and Louisiana for this period. All the issues published in New Mexico and the majority in Texas and California used English and Spanish and included translations during this period. Additionally, in California a considerably higher number of issues were classified as bilingual, which seems to point to an increasing interaction of English and Spanish in print media during this historical period.

[Table 3. Language practices during the Interaction Period]

However, despite the increasing use of English and translations in Spanish-language newspapers - particularly from the Transition Period on - the dominant language of publication continued to be Spanish. A closer analysis of the newspaper issues reveals that the translations were located throughout the newspapers in similar sections throughout the different historical periods, while the use of English was restricted to specific sections.

The first identified translated texts were advertisements translated from French into Spanish in the newspaper L'Abeille, which was originally published exclusively in French. In most cases, both versions of the advertisement appeared on the page side-by-side. When English became the main language of publication of this newspaper in 1830, some advertisements and news started to be translated from English into French for the French section.

During the Transition Period and the Interaction Period, advertisements remained the most frequently translated newspaper text type. Typically translated from English and published solely in Spanish, the advertisements were quite varied and were focused on products (e.g., vehicles, shoes, firearms, music players), businesses and restaurants (e.g., barber shops, furniture stores, pharmacies, bakeries), as well as public events and professional services (e.g., translators, lawyers, teachers, dentists, opticians). It is very likely that editorial boards had a translator in charge of the translation of advertisements. A few of the issues analyzed during the Transition Period specifically stated that all advertisements were translated into Spanish: "All advertisements or other matter sought to be published, carefully translated into Spanish from the English, French or Italian languages" (La Voz del Nuevo Mundo, 17 December 1881). During the Interaction Period, some newspapers such as El Paso del Norte printed the name of the translator right after the name of the editor-in-chief of the newspaper (see Figure 2).

[Figure 2. Header of El Paso del Norte (12 March 1904)]

Most advertisements followed a foreignizing translation approach ${ }^{8}$ by retaining the original names of businesses and products in English on the advertisements in Spanish and favoring English syntax (see Figures 3, 4 and 5).

\footnotetext{
${ }^{8}$ Foreignizing refers to a translation approach that emphasizes the source language by “"bending' TL [target language] word-usage to try to ensure faithfulness to the ST [source text]" (Munday 2013: 48).
} 
[Figure 3, 4 and 5. Translated advertisements (left to right): Figure 3-El Ciudadano, 12 March 1892; Figure 4 - Dos Republicas, 3 March 1894; Figure 5 - Evolución, 16 May 1918]

Despite the foreignizing tendencies, advertisements often included explicitations in the Spanish language version to facilitate the comprehension of information provided in English. Explicitations took the form of explanatory phrases or translations of proper names. ${ }^{9}$ In Figure 6 , after the proper name "Contra-Costa Ferry" the explanatory phrase "o sea" (in other words) is included followed by a translation in Spanish "Servicio de Contra Costa." In Figure 7, the meaning of the proper name of the construction business "Little" is explained in parenthesis as "indica chiquito" (denotes little). In Figures 8 and 9 the original names of the stores are maintained but a Spanish translation is offered as well.

[ Figure 6, 7, 8 and 9. Translated advertisements (clockwise) Figure 6 - Crónica, 15 December 1855; Figure 7 - Evolución, 8 July 1917; Figure 8 - Monitor, 5 September 1890; Figure 9 Evolución, 27 April 1917]

In addition to advertisements, editorial information and notices about the newspapers were often translated from Spanish into English and published in both languages (see Figure 10).

[Figure 10. Header published in Spanish and English (Estrella, 4 March 1911)]

In some newspapers, these translations tended to be freer and included slightly different information for the English-speaking audience. The following extracts were taken from the Californian newspaper La Gaceta published on August 9, 1879 (our translation):

Se insertan avisos á precios moderados y se solicitan agentes y corresponsales por todo el Estado. También en esta oficina se hace toda clase de trabajo de imprenta e Español e Inglés á precios cómodos. [Advertisements are published at affordable prices and agents and correspondents are requested throughout the state. All kinds of printing services in English and Spanish are carried out in this office at affordable prices.]

La Gaceta being the only newspaper published in the Spanish language in this county is an excellent advertising medium for those of our merchants who desire to bring to notice of the Spanish-speaking population of this section their wares and merchandise.

Advertisements inserted at moderate rates.

Occasionally, official announcements and documents were published in the newspapers, such as telephone directories, sworn statements, and wills. Some newspapers provided these texts in both English and Spanish, while others only printed a Spanish-language version. In 1917, for instance, the Texas newspaper Evolución published instructions for voting in Spanish. Similar to the advertisements described above, translations of these types of official texts tended

\footnotetext{
${ }^{9}$ Translation procedure whereby "implicit information in the ST is rendered explicit in the TT" (Munday 2013: 92).
} 
to follow a foreignizing approach and favored word-for-word translations.

News articles were also translated from time to time and published in Spanish. It is difficult to determine which issues included translated news since the provenance of the article is rarely indicated. However, some newspapers indicated the source and, at times, the name of the translator. For instance, on December 27, 1865 the Texan newspaper Zaragoza published several news in Spanish that had been originally published in the following national English-language newspapers: The New Orleans Times, J.I. Evening Post, Boston Sunday Herald, and New York Evening Post.

A final set of text types that was published in some of the analyzed newspapers were teaching materials and pieces of literature translated from English into Spanish. For example, on May 12, 1883, La Voz del Nuevo Mundo published a Spanish translation of Charles Dickens' "A Child's Dream of a Star" and a New Mexican newspaper, El Promotor Escolar, published regularly English lessons and activities with Spanish explanations.

To address the third research question, the issues were analyzed to determine whether the newspapers followed some type of anglicizing pattern. The main language of most analyzed newspaper issues was Spanish (95.7\%), with only a few issues having either English (ten, 1.9\%) or French (six, 2.4\%) as their main language. Seven out of the ten English-language issues belonged to The Laredo Times, a bilingual newspaper published in Texas during the twentieth century that included a section with classified advertisements in English and Spanish and a section completely in Spanish entitled El Tiempo de Laredo. The first issues of The Laredo Times had a classified advertisements section that was divided into two parallel columns: English on the left, "The Times' Classified Columns," and Spanish on the right, "Los Avisos Clasificados." Some of the advertisements in the Spanish column were translations of advertisements in the English column (see Figure 11). A bilingual announcement located at the top of both columns with advertisement policies and publication rates reveals that advertisers had the choice of publishing either in English or Spanish or in both English and Spanish. This policy may be an indicator that the newspaper itself provided translation services for these advertisements. On the issues published after February 3, 1929 the English column took considerably more space, eliminating the Spanish column's title and limiting its publishing space. Spanish advertisements continued to be published in subsequent issues, but a clear preference was given to English-language advertisements. The Spanish section entitled El Tiempo de Laredo focused on local, regional and Mexican news and was directed and edited by the Mexican educator, writer and self-taught printer, Jose García Roel.

[Figure 11. Example of translated advertisement (El Tiempo de Laredo, 3 June 1929)]

The remaining three English-language issues and all the French-language issues belonged to L'Abeille. Published in Louisiana between 1827 and 1830, L'Abeille was originally written only in French. An English-language section was added on November 24, 1827 and a Spanish one on September 1, 1829. The Spanish-language section disappeared after 1830 and English became the main language of the newspaper, published as The Bee by then (see Figures 12, 13 
and 14).

[Figure 12. Header of L'Abeille in French (5 January 1929)]

[Figure 13. Header of L'Abeille in Spanish (30 January 1930)]

[ Figure 14. Header of L'Abeille in English (5 December 1931)]

English use was limited in scope and localized to specific sections (mainly the advertisement area). Editorial information was often offered in English and some newspapers published advertisements completely in English. Interestingly, many newspapers promoted the learning and of Spanish and some even encouraged the English-speaking population to learn the language from the newspapers:

The best edited and has the largest circulation of any Spanish paper in Southern New Mexico. Commends itself to students of the Spanish language.

(El Demócrata, 24 November 1894)

Our circulation extends throughout New Mexico, Arizona, Colorado, Texas, California and the Republic of Mexico. We compete in advertising rates and job work with any publication in the West. Students of the Spanish language should read El Labrador.

(4 October 1901)

News articles were rarely published in English, but a few newspapers toward the end of the nineteenth century and the beginning of the twentieth century such as El Promotor Escolar and El Defensor started to include articles completely in English.

In sum, the analysis suggests that the first translations started to appear during the Mexican Period in Louisiana and that its presence increased steadily during the following periods in all borderland states. A detailed analysis of the nature of the translations across newspapers and sociohistorical periods seems to indicate that translations were located in specific sections, with the great majority appearing in the advertisement section. Advertisements, typically translated from English and published exclusively in Spanish, ran the gamut in terms of their focus and most of the translations could be described as foreignizing in their approach since they largely favored English syntax and included elements in the source language. In addition, some newspapers started to use English and Spanish from the Mexican Period; however, the use of English remained limited and localized.

\section{Discussion}

It is not surprising that the first issues with translations and English-language sections started to circulate in Louisiana during the Mexican Period since the French, English, and Spanish languages had been in contact in the region since the end of the eighteenth century. However, the 
study does not find strong evidence of a pattern of anglicization despite the societal shift from Spanish into English provoked by aggressive anglicizing legislation which banned Spanish during the Transition Period and the Interaction Period. While a few of the newspapers gradually increased their use of English, most continued to use Spanish as the main language throughout the different historical periods. The newspapers tended to favor content development in Spanish, and when English materials had to be published, it was translated and published in Spanish. The translation strategies show that careful thought was given to the needs of the Hispanic community. Through a foreignizing-oriented approach which tended to follow a word-for-word translation and deliberately introduced elements in English, translators ensured that the Hispanic population could manage in a bilingual and bicultural public sphere. The language and translation practices described in the previous section reflect the sentiments of the Hispanic media toward the use and maintenance of Spanish. The following quotes from the newspapers El Labrador (3 May 1912) and El Atalaya Bautista (15 December 1917), respectively, serve to illustrate the linguistic stance the Hispanic newspapers adopted:

Todos los Hispano-Americanos sabemos con anterioridad que el español es un recurso nacional en el estado de Nuevo México, por consiguiente es la lengua natal del estado. Pero el gobierno ha negado al pueblo la enseñanza exclusiva del español, y ha hecho imperativo que el inglés sea el idioma predominante, aún entre los mismos nativos. Así es que el español ha sido neglegido, por el pueblo Hispano-Americano (...). Pero éste [el español] se está haciendo un caso de absoluta necesidad (...), no sólo en asuntos comerciales pero también sociales. [All Hispanic-Americans know that Spanish is a national resource of the state of New Mexico, therefore it is the native language of the state. But the government has denied the people the exclusive teaching of Spanish, and has made it imperative that English be the predominant language, even among native speakers. Thus, Spanish has been neglected by the Hispanic-American people (...). But it [Spanish] is absolutely necessary (...), not only for trade purposes but also social ones.]

Haremos y publicaremos muy pocas traducciones, porque deseamos que el periódico sea en cuanto se pueda, original y de un sabor puramente nacional; por lo cual invitamos cariñosamente a todos los ministros, maestros y demás obreros nacionales para que colaboren con nosotros en esta obra eminentemente nacional. [We will do and publish very few translations, because we want the newspaper to be, as much as possible, original and of a purely national flavor. Therefore, we warmly invite all ministers, teachers, and other national workers to collaborate with us in this predominantly national work.]

While the first quote emphasizes the status of Spanish as a resource in the context of the borderlands regardless of the discriminatory language policies in place at the time, the second clearly promotes the creation and publication of original material in Spanish. 


\section{Conclusion}

Historically, language policies in the United States have been characterized by a contentious imposition of English across social domains and a devaluation of minority languages and their communities. Despite the large number of Hispanics residing today in the country, the percentage of Hispanics who speak Spanish has started to decline. Due to the decreasing intergenerational transmission rates and the aggressive English-only pressures, the long-term maintenance of Spanish in the United States cannot be guaranteed. In spite of that, a number of researchers (e.g., Kanellos and Martell 2000; Kanellos 2011; Carreira 2013) have emphasized the determining role of the media in the defense of the Hispanic community and the maintenance of the Spanish language. Since the publication of the first Spanish-language newspapers in the southwest of the present United States at the beginning of the nineteenth century, Hispanic publications have resisted acculturation and assimilation to the Anglo-Saxon culture and the English language by raising the visibility of the Spanish language and communicating a predominantly English-dominant bicultural reality in Spanish.

The analysis of the language and translation practices of Hispanic newspapers published in the U.S. borderlands from 1808 to 1930 suggests an adherence to the Spanish language in all states and during all the historical periods studied. An increased use of English was observed in a few newspapers - specifically after 1848 - but Spanish continued to be the main language of publication. Generally speaking, content creation was carried out in Spanish and English texts were translated and published in Spanish.

In sum, regardless of the socioeconomic and political Anglo-American domination after the annexation and the enforcement of English-only policies in the borderlands, Hispanic newspapers did not yield entirely to the anglicizing pressures. Hispanic publishers, editors, and journalists continued to defend and promote the Spanish language through a generalized use of the language.

\section{Address for correspondence}

Laura Gasca Jiménez

Fairfield University

1073 N Benson Rd, Canisius Hall, 314

Fairfield, CT 06824

USA

lgascajimenez1@ fairfield.edu

\section{Biographical notes}

Laura Gasca Jiménez is an Assistant Professor of Spanish and Translation Studies in the Department of Modern Languages and Literatures at Fairfield University. She is the recipient of a "la Caixa" Foundation Fellowship and holds a Ph.D. in Hispanic Linguistics from the University of Houston and a M.A. in Translation from Kent State University. Her main research 
areas are translation and interpreting pedagogy, bilingualism and multilingualism, second language acquisition, and heritage language education.

\section{https://orcid.org/0000-0003-1363-5470}

Maira E. Álvarez is the Director of the Houston Office of the Inter-University Program for Latino Research (IUPLR). Her research interests lie on the study of U.S. Latino, U.S.-Mexico Border, Latin American Literature as well as Border and Women's Studies, Digital Humanities, archival material, art, and print culture. She is co-founder of Borderlands Archives Cartography (BAC), team member of Torn Apart / Separados, and a member of the forthcoming team-based digital humanities project United Fronteras.

Sylvia Fernández is a Ph.D. candidate in the Department of Hispanic Studies at the University of Houston. Currently, she is writing her dissertation titled "Genealogía transfronteriza: Mujeres en la literatura y cultura de la frontera México-Estados Unidos" and has co-founded and participated in various digital humanities projects. Her research interests include U.S. Latino/a and Latin American literature, border studies, Hispanic archives, digital humanities, women's, gender and sexuality studies, and de/post-colonial theory.

\section{References}

Argudín, Yolanda. 1987. Historia del periodismo en México desde el virreinato hasta nuestros días. México: Panorama editorial.

Balestra, Alejandra, Glenn A. Martínez, and María I. Moyna. 2008. Recovering the U.S. Hispanic Linguistic Heritage: Sociohistorical Approaches to Spanish in the United States. Houston, Tex.: Arte Público Press.

Bills, Garland D., Eduardo Hernández-Chávez, and Alan Hudson. 1995. "The Geography of Language Shift: Distance from the Mexican Border and Spanish Language Claiming in the Southwestern US." International Journal of the Sociology of Language 114 (1): 9-28.

Carreira, María. 2013. "The Vitality of Spanish in the United States." Heritage Language Journal 10 (3): 103-120.

Castañeda, Carlos E. 1940. "The Beginning of Printing in America." The Hispanic American Historical Review 20 (4): 671-685.

Center for Spanish Language Media. 2011. "State of Spanish Language Media: 2011 Annual Report." Accessed June 1, 2017. http://www.slideshare.net/alcancemg/state-of-spanishlanguage-media.

Fishman, Joshua A. 1964. "Language Maintenance and Language Shift as a Field of Inquiry. A Definition of the Field and Suggestions for its Further Development." Linguistics 2 (9): $32-70$. 
Garner, Jane. 1987. "Flying Sheets, Early Newspapers Important to Scholarly Inquiry." The General Libraries Newsletter Fall 1987: 3-5.

Gutiérrez, Félix. 1977. "Spanish-language Media in America: Background, Resources, History." Journalism History 4 (2): 34-68.

Hernández-Chávez, Eduardo. 1993. Native Language Loss and its Implications for Revitalization of Spanish in Chicano Communities. In Language and Culture in Learning: Teaching Spanish to Native Speakers of Spanish, edited by Merino, Barbara J., Henry T. Trueba, and Fabián A. Samaniego, 58-74. London: Falmer.

Kanellos, Nicolás. 1993. "A Socio-historic Study of Hispanic Newspapers in the United States." In Recovering The U.S. Hispanic Literary Heritage, Volume I, edited by Ramón A Gutiérrez and Genaro Padilla, 107-128. Houston: Arte Público Press.

---. 1995. Chronology of Hispanic-American History. Detroit: Gale Research Inc.

---. 2011. Hispanic Immigrant Literature: El Sueño del Retorno. Austin: University of Texas Press.

Kanellos, Nicolás, and Helvetia Martell. 2000. Hispanic Periodicals in the United States, Origins to 1960: A Brief History and Comprehensive Bibliography. Houston: Arte Público Press.

Kanellos, Nicolás, and Alejandra Balestra. 2002. En otra voz: antología de la literatura hispana de los Estados Unidos. Houston: Arte Publico Press.

Kloss, Heinz. 1977. The American Bilingual Tradition. Rowley, Massachusetts: Newbury House Publishers.

Lazo, Rodrigo, and Jesse Alemán. 2016. The Latino Nineteenth Century: Archival Encounters in American Literary History. New York: New York University Press.

Leal, Luis. 1973. "Mexican American Literature: A Historical Perspective." Revista chicanoriqueña 1 (1): 32-44.

Meléndez, Gabriel A. 2005. Spanish-language Newspapers in New Mexico, 1834-1958. Tucson: University of Arizona Press.t

Montrul, Silvina. 2002. "Incomplete Acquisition and Attrition of Spanish Tense/Aspect Distinctions in Adult Bilinguals." Bilingualism: Language and cognition 5 (01): 39-68.

---. 2005. "Second Language Acquisition and First Language Loss in Adult Early Bilinguals: Exploring Some Differences and Similarities." Second Language Research 21 (3): 199_ 249.

---. 2016. The Acquisition of Heritage Languages. Cambridge: Cambridge University Press.

Munday, Jeremy. 2013. Introducing Translation Studies: Theories and Applications. New York: Routledge.

Otheguy, Ricardo, and Ana C. Zentella. 2012. Spanish in New York: Language Contact, Dialectal Leveling, and Structural Continuity. New York: Oxford University Press.

Perrigo, Irwin L. 1960. Our Spanish Southwest. Dallas: Banks Upshaw. 
Pew Research Center. 2016a. "Statistical Portrait of Hispanics in the United States." Accessed May 2, 2017. http://www.pewhispanic.org/2016/04/19/statistical-portrait-of-hispanics-inthe-united-states-key-charts/.

---. 2016b. "The Nation's Latino Population Is Defined by Its Youth." Accessed May 2, 2017.

http://www.pewhispanic.org/2016/04/20/the-nations-latino-population-is-defined-by-itsyouth/.

Potowski, Kim. 2010. Language Diversity in the USA. Cambridge: Cambridge University Press

Rivera-Mills, Susana V. 2009. "Latinos or Hispanics? Changing Demographics, Implications, and Continued Diversity." Southwest Journal of Linguistics 28 (2): 1-21.

Rosales, Arturo F. 2000. Testimonio: A Documentary History of the Mexican-American Struggle for Civil Rights. Houston: Arte Público Press.

Silva-Corvalán, Carmen. 1994. Language Contact and Change: Spanish in Los Angeles. Oxford: Clarendon Press.

Silva-Corvalán, Carmen. 2001. Sociolingüística y pragmática del español. Washington, DC: Georgetown University Press.

Treviño, Roberto R. 1989. Becoming Mexican American: The Spanish-language Press and the Biculturation of Californio Elites, 1852-1870. Stanford Center for Chicano Research.

\section{Appendix}

\begin{tabular}{|l|l|l|c|}
\hline \multicolumn{1}{|c|}{ Newspaper } & \multicolumn{1}{c|}{$\begin{array}{c}\text { Publication } \\
\text { period }\end{array}$} & \multicolumn{1}{c|}{ Publication place } & $\begin{array}{c}\text { Number of } \\
\text { issues analyzed }\end{array}$ \\
\hline El Misisipí & $1808-1810$ & New Orleans, Louisiana & 3 \\
\hline El Mexicano & $1813-181 ?$ & Natchitoches, Louisiana & 1 \\
\hline La Gaceta de Texas & $1813-1813$ & Natchitoches, Louisiana & 6 \\
\hline L'Abeille (La Abeja) & $1827-1830$ & New Orleans, Louisiana & 9 \\
\hline Verdad & $1844-1845$ & Santa Fe, New Mexico & 3 \\
\hline El Clamor Público & $1855-1859$ & San Francisco, California & 1 \\
\hline El Amigo del Pueblo & $1861-1 ? ? ?$ & Los Ángeles, California & 2 \\
\hline El Zaragoza & $1865-186 ?$ & Brownsville, Texas & 3 \\
\hline El Joven & $1877-1878$ & Los Ángeles, California & 2 \\
\hline El Aguacero & $1878-1 ? ? ?$ & Los Ángeles, California & 21 \\
\hline El Eco de la Patria & $1878-1 ? ? ?$ & Los Ángeles, California & 1 \\
\hline La Gaceta & $1879-1881$ & Santa Barbara, California & 7 \\
\hline Laredo Times & $1881-188 ?$ & Laredo, Texas & 5 \\
\hline El Demócrata & $1882-1882$ & Los Ángeles, California & 2 \\
\hline La Fe en la Democracia & $1884-1884$ & Los Ángeles, California & 5 \\
\hline El Eco Mexicano & $1885-1885$ & Los Ángeles, California & 14 \\
\hline El Monitor & $1889-1895$ & Nogales, Arizona & 4 \\
\hline El Monitor & $189 ?-1 ? ? ?$ & El Paso, Texas & \\
\hline El Hispano Americano & $189 ?-1 ? ? ?$ & El Paso, Texas & \\
\hline
\end{tabular}




\begin{tabular}{|c|c|c|c|}
\hline La Opinión Pública & $189 ?-1 ? ? ?$ & El Paso, Texas & 11 \\
\hline El Defensor del Pueblo & $1890-1892$ & Mesilla, New Mexico & 3 \\
\hline Latino Americano & 1891-1891 & El Paso, Texas & 26 \\
\hline El Promotor Escolar & 1891-1892 & Las Cruces, New Mexico & 21 \\
\hline El Ciudadano & $1892-1 ? ? ?$ & El Paso, Texas & 5 \\
\hline Las Dos Repúblicas & $1892-1898$ & Los Ángeles, California & 2 \\
\hline La Flor del Valle & 1894-1??? & Las Cruces, New Mexico & 6 \\
\hline El Demócrata & 1894-1894 & Las Cruces, New Mexico & 2 \\
\hline Unión & $1895-1912$ & Los Ángeles, California & 1 \\
\hline El Eco Fronterizo & 1896-1??? & El Paso, Texas & 2 \\
\hline La Empresa & 1896-1??? & Las Cruces, New Mexico & 4 \\
\hline El Labrador & 1896-1914 & Las Cruces, New Mexico & 4 \\
\hline El Demócrata fronterizo & $1896-1920$ & Laredo, Texas & 1 \\
\hline Verdad & 1898-1??? & Las Cruces, New Mexico & 6 \\
\hline Voz del Nuevo Mundo & $18 ? ? ?-1 ? ? ?$ & San Francisco, California & 2 \\
\hline El Monitor Mexicano & $18 ? ?-19 ? ?$ & Los Ángeles, California & 1 \\
\hline El Progresista & $18 ? ?-19 ? ?$ & El Paso, Texas & 5 \\
\hline La Democracia & 190?-19?? & El Paso, Texas & 8 \\
\hline El Paso del Norte & 1904-1918 & El Paso, Texas & 1 \\
\hline Regeneración & 1904-1918 & Los Ángeles, California & 2 \\
\hline Correo Mexicano & 1907-19?? & Los Ángeles, California & 5 \\
\hline La Crónica & 1909-19?? & Laredo, Texas & 4 \\
\hline El Atalaya Bautista & $191 ?-19 ? ?$ & El Paso, Texas & 16 \\
\hline El Día & 191?-19?? & El Paso, Texas & 21 \\
\hline El Correo del Bravo & 191?-19?? & El Paso, Texas & 1 \\
\hline Mefistófeles & 191?-1918 & San Francisco, California & 8 \\
\hline La Estrella & 191?-1939 & Las Cruces, New Mexico & 4 \\
\hline La Prensa & 1912-1924 & Los Ángeles, California & 4 \\
\hline La Crónica & 1914-1917 & San Francisco, California & 7 \\
\hline La Justicia & $1915-1916$ & El Paso, Texas & 2 \\
\hline Evolución & 1916-19?? & Laredo, Texas & 1 \\
\hline El Cronista del Valle & 1917-19?? & Brownsville, Texas & 1 \\
\hline El Independiente & 1917-19?? & Mountainair, New Mexico & 1 \\
\hline La Gaceta Popular & 1918-192? & Las Cruces, New Mexico & 2 \\
\hline La Patria & 1919-19?? & El Paso, Texas & 1 \\
\hline El Azote & 192?-19?? & El Paso, Texas & 5 \\
\hline La Buena Prensa & 1923-19?? & El Paso, Texas & 1 \\
\hline Las Noticias & 1923-19?? & El Paso, Texas & 1 \\
\hline Renacimiento & 1923-19?? & El Paso, Texas & 3 \\
\hline El Malcriado & 1923-1930 & Los Ángeles, California & 11 \\
\hline El Defensor & 1929-1932 & Edinburg, Texas & 24 \\
\hline El Clarín del norte & 19??-19?? & El Paso, Texas & 1 \\
\hline
\end{tabular}

